\title{
Why Is Fiscal Policy Procyclical in MENA Countries?
}

\author{
Sarra BEN SLIMANE \\ Department of Economic \\ Faculté de Droit et des Sciences Economiques et Politiques de Sousse \\ Cité Erriadh, 4023, Sousse, Tunisie \\ LEFA, IHEC Carthage \\ DEFI, Université de la Méditerranée, Aix Marseille II \\ E-mail: Sarra.BEN-SLIMANE@univmed.fr \\ Moez BEN TAHAR (corresponding author) \\ Université de Nice Sophia Antipolis, CEMAFI, Avenue Doyen Louis Trotabas 06050 Nice, France \\ LEFA, IHEC Carthage \\ E-mail: ben.tahar.moez@etu.unice.fr
}

\begin{abstract}
The optimal fiscal policy is countercyclical, aiming to keep the output close to its potential. Nevertheless, it has been pointed out that developing countries are unable to run countercyclical fiscal policies. Several researchers have attributed these sub optimal fiscal policies to two groups of arguments. (i) The limited access to domestic or external funds may hinder the ability of government to pursue expansionary fiscal policy in bad time. (ii) The second group of factors explains that sub-optimal fiscal policies are associated with institutional theories. The standard argument suggests that countries pursuing poor fiscal policies have, also, weak institutions, widespread corruption, and lack of property rights and repudiation of contract.

The main goal of this paper is to analyze empirically if the ability of MENA countries to conduct countercyclical fiscal policy is affected by the quality of their institutions, the nature of political regime and/or by the availability of financial resources either on the local or international capital markets.

From our fiscal policy regression, we find that government expenditure in MENA region is procyclical. We conclude that MENA countries are unable to run countercyclical fiscal policies if they have weak institutions, small access to international, domestic credit market, and democratic political regime.
\end{abstract}

Keywords: Fiscal policy, Business cycle, Cyclical proprieties, MENA region, Financial market, Quality of institution, Democracy, Oil and Gas rents

JEL Classifications: E62, E32

\section{Introduction}

Compared to the large literature on determinants of economic growth, there has been less research on the cyclical behaviour of macroeconomic aggregates in developing countries. Understanding the factors underlying the cyclical dynamics of macroeconomic aggregates is very important for two reasons. (i) First, examining the co-movement between economic activity and fiscal policy has analytical value from the perspective of the business cycle modelling (Akitoby et al [2004]); (ii) second, this type of analysis can make a valuable contribution to the design of stabilization and adjustment program (Agénor and Montiel [1996]).

A large growing literature has argued that there is a fundamental difference between how fiscal policy is conducted in developing countries compared to industrial countries. While fiscal policy in industrial countries is either a-cyclical or countercyclical, fiscal policy in developing countries is, mostly, procyclical. Gavin and Perotti [1997] were the first to call attention to the fact that fiscal policy in Latin America appeared to be procyclical. Talvi and Végh [2005] claimed that procyclical fiscal policy seemed to be the rule in the developing world.

Until now, a large number of papers have reached similar conclusions to the point that procyclical of fiscal policy in developing countries has become part of the conventional wisdom (Braun [2001], Kaminsky, Reinhart and Végh [2004], Alesina and Tabellini [2005], Manasse [2006], Ilzetski et al [2008]...).

It was argued that the ability of developing countries to adopt optimal stabilization fiscal policy is loaded by several factors, which can be classified in two groups. 
Structural arguments: limited access to domestic or external funds may hamper the ability of government to pursue expansionary fiscal policy in bad time (Gavin and Perotti [1997], Riascos and Végh [2003], Caballero and Krishnamurthy [2004]).

Institutional arguments: the second group of factors that explains sub-optimal fiscal policies is associated with the institutional theories. The standard argument suggests that countries pursuing procyclical fiscal policies have, also, weak institutions- widespread corruption, lack of property rights and repudiation of contract.

Our paper complements and extends the recent literature by (i) offering a new empirical framework to assess and explain cyclical proprieties of fiscal policy in MENA countries. Empirical research about fiscal policy cyclicality in MENA region is inexistent and previous works focus only on Latin American and African's countries. (ii) Testing more, exhaustively, the effect of political and institutional determinants. (iii) Assessing, simultaneously, the role of intern and extern credit constraints in affecting fiscal procyclicality. In order to explain the cyclical pattern of fiscal policy in MENA region we use a large set of determinants including aspect such as financial development, financial integration, corruption, quality of institution, democracy, political completion, constraints of the executive, voracity effects.

To test these assumptions we collect data from a sample of 10 MENA countries (Egypt, Bahrain, Iran, Jordan, Lebanon, Morocco, Oman, Syria and Tunisia, Yemen) for the period from 1980 to 2007.

This paper is organized as follow. Section 2 discusses the literature on fiscal policy cyclicality with focus on theories explaining procyclicality of fiscal policy in developing countries. Section 3 examines the data and the methodology used to gauge the cyclical proprieties of fiscal indicators. Section 4 estimates and interprets fiscal policy regression for samples of MENA countries. Finally, section 5 concludes.

\section{Literature Review}

In the last decade, an important part of literature associated with fiscal policy has been addressing the issue of cyclicality. Several factors hamper the ability of developing countries to adopt optimal stabilization policies. These factors can be classified in two groups. The first corresponds to factors associated to the integration (access) to domestic and international financial markets. The main idea is that the limited access to domestic or external funds may hinder the ability of government to pursue expansionary fiscal policies in bad times.

The second group of factors is associated to theories where the institutional framework plays a key role. Within this group, one standard of the theory suggests that countries pursuing poor fiscal policies also have weak institutions.

\subsection{Structural determinants}

Gavin and Perotti [1997] argue that governments in developing countries are unable to run countercyclical fiscal policies due to the rigorous credit constraints that avoid them from borrowing during downturns. Additionally, these governments are constrained to repay their debt, which, in consequence, forced them to adopt procyclical fiscal policy.

Kaminsky, Reinhart and Végh [2004] and Alesina and Tabellini [2005] give evidence that capital inflows to developing countries are procyclical meaning that countries tend to borrow in good times and repay in bad times. This procyclical access to international capital markets forced developing countries to adopt procyclical fiscal policies. To avoid the limited access to international capital markets, in bad times, government adopts fiscal adjustment. If investors raise doubts on the ability of governments to implement required adjustment, creditworthiness would weaken and further financing would disappear.

Caballero and Krishnamurthy [2004] invoke the limited financial depth to explain procyclical fiscal policy in developing countries. Accordingly, when economy faces financial constraint to borrow, increasing government spending may crowd out private investment and, hence, may be contractionary. Caballero and Krishnamurthy [2004] point out that the contractionary effects of expansionary fiscal policies can be exacerbated if these policies lead to a deterioration of the quality of country's assets.

Aguiar, Amador and Gopinath [2005] provide explanations about the observed procyclicality of fiscal policies in emerging markets and present another mechanism through which fiscal policy amplifies the business cycle. Their explanation relies on two features of emerging markets: limited access to financial markets and limited commitment to fiscal policy. They present a small open economy model with capital where a government maximizes the utility of a working population that has no access to financial markets and is subject to endowment shocks. The government's insurance motive generates procyclical taxes on capital income. If the government lacks commitment, its fiscal policy can be distortionary. Hence, the government has stronger incentives to tax capital in the future if the economy is in recession, thus reducing capital investment, amplifying and extending the downturn. 


\subsection{Institutional and Political determinants}

Tornell and lane [1999] introduce the notion of "voracity effect" to explain the overspending of transitory increases in fiscal revenues. A positive shock to income leads to more than proportional increase in public spending, even if the shock is expected to be temporary. This, in turn, is the consequence of weak institution framework and the presence of multiple powerful groups in fiscal process.

Woo [2005] emphasizes the role of social polarization to understand procyclical fiscal stances in a number of countries. When there is polarization of social preferences over public choices, the incentives become greater for policymakers to implement their preferred policies. This individual rationality may threaten efficiency for the economy. According to the author, such incentives may become particularly stronger during boom periods, since increased revenues or new resources make their preferred policies seem easier to implement, thus producing procyclical fiscal policies.

Talvi and Végh [2005] argue that the variability of tax bases in developing countries can explain procyclicality in these countries. They developed an optimal fiscal policy model including a political distortion, which makes it costly to run budget surpluses due to the pressures that abandon fiscal resources created to increase public spending. Given this political distortion, a government that faces large fluctuations in the tax bases will choose to worse taxes in good times to dissuaded spending pressures. Given this political distortion, the best way to avoid a high growth in expenditure is to lower tax rates. This procyclical behaviour is a second-best response to that political distortion.

Alesina et al [2005] try to explain why countries follow seemingly sub optimal procyclical fiscal policies that add to macroeconomic instability. To answer this question they adopt a political approach as Talvi and Végh [2005] and focus on diving political distortions. In this paper voters face corrupt government that can appropriate part of tax revenues to finance unproductive public consumption. When voters realize that a positive income shock has affected the economy, they manifest an immediate welfare like tax cuts or increases in productive government spending and transfers. This political distortion leads to excessive accumulation of government debt and procyclical fiscal policy during both boom and recession and should be more prevalent in countries where political corruption is prevalent and the government is responsible to the voters. Alesina et al [2005] criticize the relevance of credit constrain argument (Gavin and Perotti [1997], Kaminski, Reinhart and Végh [2004], Riascos and Végh [2003]) and explain that political distortion may drive government to attempt an unsustainable level of debt corresponding to what they can repay and therefore at the limit of what borrowers can lend. Consequently, credit constrain is a direct consequence of the political agency problem and implies that fiscal policy should be procyclical only in recession.

\section{Empirical Strategy and Data}

Understanding the factors underlying fiscal cyclicality has been a subject largely explored in the literature. However, this intense research generally tends to concentrate on industrial and emerging countries and gives little space to MENA countries.

The main objective of this paper is to characterize and explain the cyclical proprieties of fiscal policy in MENA region. We search also to establish the differences in the cyclicality of fiscal indicator between oil- producing and non-oil producing MENA countries.

We underline the role of institutional quality, political regimes, international financial integration, and financial development and are going to determine the ability of government to conduct countercyclical fiscal policies.

Our empirical strategy consists of two stages: we first estimate the cyclicality of fiscal policy and then move on looking at how cyclicality is affected by different factors. Following recent work by Hercowitz and Strawczynski [2004], Alesine and Tabellini [2006] and Calderon and Schmit-hebbel [2008]. In the first stage, we estimate the following policy regression equation to determine the cyclicality of fiscal policy.

$$
\Delta F_{i, t}=\alpha+\phi F_{i, t-1}+\beta \Delta Y_{i, t}+\theta Z_{i, t}+\mu_{i}+\varepsilon_{i, t}
$$

The variable $F_{i, t}$ corresponds to fiscal indicator- central government real total expenditure - for each country. Consistent with argument developed by Kaminsky, Reinhart [2004] cyclicality is seen through policy instrument variables rather then outcome variables. We therefore use real total government expenditure to assess the cyclicality proprieties of fiscal policies. $Y_{i, t}$ is the real gross domestic product. $\Delta$ represent the difference operator. $\mu_{t}$ is a country level fixed effect. $Z_{i, t}$ include control variables (trade openness, the rate of inflation, growth in terms of trade, dependency ratio, and urbanization ratio).

Trade of openness, is more important since open economies are more prone to external risks, so that government should promote consumption smoothing through a countercyclical policy. 
Dependency ratio, include the share of population over 65 years. Countries with large share of retired people will feel greater pressure on their security system. Woo [2003] and Venes [2006] use this control.

Inflation rate of consumer price index, Woo [2003] explains that inflation can affect fiscal deficit through different channels. Rising inflation, raise fiscal deficit through higher nominal interest payments. Higher inflation can lead also to lower real tax revenue.

We take account of growth in terms of trade to control for external shocks to the economy. External shocks can be important sources of fiscal instability, especially in developing countries. Improvement in terms of trade promotes economic activities and reduces government social transfers. However, decreasing in terms of trade weakens economies, and leads to increase government spending to hedge against adverse external shocks

We include the ratio of urban population to total population, we consider that infrastructure constitute the most part of public investment. A higher degree of urbanisation will reduce the demand for infrastructure because rural areas that needs it most.

It exist many arguments leading us to expect that an OLS estimate of equation 1 be biased. The first is the problem of endogeneity. In fact, the reserve causality problem pervasive any attempt to estimate cyclicality of fiscal policy: the growth in government spending affect output growth. Another problem is the possible correlation of all regressors with the country fixed effect $\mu_{t}$.

To resolve these problems we reject OLS estimators and we use dynamic panel GMM estimators. We take data on first difference, this method take out the fixed effect from the equation, and allow us for using internal instruments for both the endogenous regressor and the lagged independent variable. These methods are very suitable in cases for which they are no exogenous instruments available (Roodman [2006]). Despite the literature has identified several exogenous instruments for GDP growth, we conclude that none of these are particularly adequate for MENA countries. For this reasons we choose to report only GMM estimates using internal instruments without comparison to OLS and 2OLS estimates.

In our second stage, we estimate the following equation:

$$
\Delta F_{i, t}=\alpha+\phi F_{i, t-1}+\beta_{0} \Delta Y_{i, t}+\beta_{1} X_{i, t} \times \Delta Y_{i, t}+\theta Z_{i, t}+\mu_{i}+\varepsilon_{i, t}
$$

The sign and size of coefficient $\beta_{0}$ determine the cyclicality of fiscal indicator. If $\beta_{0}<0$, fiscal policy is countercyclical; $\beta_{0}=0$ is acylical and if $\beta_{0}>0$ it is procyclical.

This equation unable us to look our estimated cyclicality coefficient is affected by different factors $X$. As $\beta=\beta_{0}+\beta_{1} X_{i, t}$ it is easy to see that the decrease in procyclicality will depend on the values estimated for $\beta_{1}$ and changes in the factors it self: decreases in the factor will decrease procyclicality if $\beta_{1}>0$; and increase procyclicality if $\beta_{1}<0$.

\section{Financial Depth}

Several papers have argued that many countries may be unable to run countercyclical fiscal policies due to an inadequate supply of credit. In fact, fiscal deficits may be more easily financed by the issuing of bonds (this avoiding inflationary finance) by countries with more highly developed financial market.

According to Gavin and Perotti [1997], developing countries are more prone to run procyclical fiscal policies due to a lack access to domestic and international credit market. Caballero and Krishnamurthy [2004] consider that emerging countries are unable to pursue expansionary fiscal policy during downturns because they have limited financial depth. Following this idea, we include a variable $F D$-domestic credit to private sector expressed as percentage of GDP- as a measure of financial development. We expect that higher values of $F D$ (more developed system) have a countercyclical effect on fiscal policies.

\section{Financial integration}

Our outcome measure of financial openness involves data on foreign data assets and liabilities from Lane and Milesi-Ferretti [2007]. We construct the ratio of foreign liabilities as a percentage of GDP (which include stocks of liabilities in portfolio equity, foreign direct investment, debt and financial derivatives). We include financial openness variable to give evidence that capital inflows in MENA countries are procyclical that is countries tend to borrow in good times and repay in bad times. This procyclical access to international capital markets may lead to procyclical fiscal policies and, hence, higher aggregate volatility. 


\section{Quality of institutions}

We use the index of political risk, from ICRG [2008], in order to take into account the effect of the absence of strong and political institutions and the presence of different powerful groups in society. The index of political risk (0-100) comprises indicators on government stability, socio-economic conditions, investment profile, internal conflict, external conflict, corruption, military in politics, religious tensions, rule of law, ethnic tensions, democratic accountability, and the quality of the bureaucracy. As Caldéron and Schmidt-hebbel [2008], we test the following hypothesis: are fiscal policies in countries with strong institutions able to stabilize business cycle fluctuations?

\section{Corruption}

Alesina and Tabellini [2005] argue that procyclical fiscal policy is observed in countries where political corruption is widespread and government are accountable to voters because voters believe the government will misappropriate resources and thus they demand higher government spending. However, other authors have stressed different linkages between corruption and fiscal policy. Tanzi and Davoodi [1997], Friedman et al. [2000] and Ghura [2002] provide evidence that corruption leads to lower levels of tax collection and hence to sub-optimal government spending. Thus, butter governance (lower corruption) may do nothing to make fiscal policy les countercyclical: it may simply increase resources (tax revenue) available to support additional procyclical government spending.

\section{Natural resource rent}

Natural resource rent may be regarded as a gift from Nature, because in theory it can be taxed away by governments without impairing incentives to produce. A high ratio of natural resource rent/GDP can facilitate economic development if the rent is used to boost levels of investment and the foreign exchange from resource exports is deployed to enhance the capacity to import the capital goods required to build a modern economy. The inferior performance of resource-rich countries can be attributed to two characterizes commonly associated with resource abundance. First, competition for the rent tends to engender "extractive" political states. This is because rent extraction is more attractive to government than wealth creation. Second, the deployment of rent by an "extractive" government is motivated by the desire of an incumbent government to stay in power and this implies incurring in political trade-off that are necessary in order to keep other powerful interest groups aligned with and supportive of the current regime. While incumbent government in resource-rich economies may very well have a development model that they believe will generate better economic and social welfare outcomes, the trade-offs that they are obliged to make and the exogenous economic consequences associated with the extraction and trade of natural resource combined will introduce distortions to structure of the economy and in the quality of governance institutions of the country. This political distortion leads to excessive accumulation of government debt and procyclical fiscal policy during both boom and recession.

In this paper we propose new variable as possible determinant of cross country differences in the cyclical pattern of fiscal policy. In this respect we introduce Petrol and Gas rent to GDP to measure natural resource rent in MENA region. We use this variable as possible determinant of fiscal policy cyclicality through the impact of natural resource rent on governance and quality of institution level of a country. We assume that natural resource rent affect procyclicality through creation of political distortion leading to excessive accumulation debt and procyclical fiscal policy. We draw this variable from World Bank database

\section{Democracy}

We include the nature of the political regime as measured by the polity score from the Polity IV codebook. Here we use polity score defined as the difference between the index of institutionalized democracy $(0-10)$ and the index of institutionalized autocracy (0-10). This leads to an indicator that takes values between 10 and 10 , where negative (positive) values signal an autocratic (democratic) regime. We introduce measures of "constraints on the executive" and "political competition" to keep with growing consensus over other dimensions of democracy. These indicators were drawn from Policy IV database.

\section{Voracity effect}

Tornell and Lane [1999] analyze the fiscal process in an environment where powerful groups of interest interplay in a society with weak legal and political infrastructure. In this model, the intensity of fiscal competition increases during upturns. For instance, in the event of positive temporary shocks to income, fiscal spending can grow more proportionally (voracity effect). All power blocs compete for a share in fiscal revenue and they do not want to reduce their appropriation rate during upturns. Hence, the government would allow groups to even increase their appropriation rate during by a larger amount and over-spend instead of saving the income windfall by running a budget surplus. 
We use the variable POLCONIIIfrom Henisz [2010] in order to account for the effect of fiscal constraints and the presence of voracity effect. A greater dispersion of power may lead to sounder fiscal policy fiscal policy by reducing the harmful effects of polarization on fiscal behaviour. Woo [2005] found that higher value of this index (a greater separation of powers) leading to more countercyclical government spending. POLCONIIIis a more recent version of POLCON. Lane [2003] uses POLCONas a proxy for the dispersion of political power, and consequently a proxy for the intensity of the voracity effect.

\section{Empirical assessment}

Our first regression for the cyclicality of real government expenditure is reported in table 1 . We find that regardless of the specification used our estimate of the cyclicality coefficient is always positive and significant. This result means that government expenditure in MENA region is countercyclical and reflects the facts that output expansion would be associated with an increase in government expenditure. Regressions suggest that government expenditure is highly procyclical, with expenditure responding more than proportionally to fluctuation in real GDP growth.

For all specification, the estimated elasticity of government spending with respect to real output growth is higher than one for MENA region. The estimate takes a large value when we include more controls in our robustness checks. We conclude that no difference between oil countries and non oil countries concerning the degree of procyclicality of government expenditure. We show that expenditures respond less than proportionally to fluctuation in real GDP growth.

we find a large significant coefficient relating to the lagged growth of public expenditure given evidence concerning the important role of the lagged level of fiscal indicator and indicating the presence of reversion behaviour and inertia phenomenon which affecting the running of fiscal policy in MENA countries.

Arellano-Bond [1991] test for first and second order serial correlation in the error term. In the first difference in the error term results are satisfactory; they suggest that the former is present but the latter is not. This result is consistent with identifying assumption of no serial correlation of the underlying error terms in equation 1.

Our results may be affected by the inclusion of control variables that are known to affect government spending and correlated to real GDP growth through channels other the cyclicality of government expenditure. Column 2 presents results obtained by including control variables. Interestingly, public expenditure rises with adverse terms of trade shocks; for other control variables the coefficients are of expected sign but nearly never statistically significant.

We report Sys-GMM estimates in column 3. This method combines differenced and level equations to obtain estimates more efficient than Diff-GMM, by including an additional assumption: past changes in the instruments must be uncorrelated with the fixed effect. It is reassuring to obtain near similar results to the Diff-GMM estimates, and we conclude that Sys-GMM is not particularly more efficient and precisely estimated.

We present the empirical assessment on the role of financial constraints on the ability of countries to run countercyclical fiscal policy. To capture the role of financial development we include the interaction between real GDP growth and a measure of financial depth. Here we use the ratio of domestic credit to private sector to GDP. Also government need to access to international financial market (and, hence, foreign borrowing) to conduct countercyclical fiscal policy. To capture the role of financial openness we include the interaction between real GDP growth and a measure of international financial integration. Here we use financial integration index from Lane and Melesi-Ferretti dataset.

Table 2 investigates the role of restrictions on both international (model 4) and domestic (model 5) financing in the cyclicality pattern of real government expenditure in MENA region. The real GDP growth coefficient is negative and significant, thus implying procyclical behaviour. The interaction between growth and access to (domestic and international) capital markets is positive and significant. It appears that characteristics of the domestic and international capital markets are relevant for cyclicality. Therefore relaxing credit constraints may give countries fiscal space to run countercyclical policies.

Several studies suggest that better political institutions should lead to less procyclical fiscal policies. The role of political determinant is captured by different variables. First we incorporate the nature of the political regime as measured by polity score from Polity IV database. Our intuition behind including the political regime is that democracies are usually characterized by heaving a larger number of veto points in the political system and a greater division of control across different political parties. That is, power is more dispersed in democracies. Second, we introduce in empirical investigation measures of "constraints on the executive" and "political competition" to keep with growing consensus over other dimensions of democracy. These indicators were drawn from Policy IV database. Finally we use POLCONIII from Henisz [2010] as proxy for the intensity of the voracity effect. 
Following table 3, the interaction between growth of real GDP and democracy is negative and significant. This results suggest that MENA countries may be able to run countercyclical policies if they do not have multiples players intervening in the fiscal process. We confirm this through the introduction of voracity effect variable. We find that the coefficient interaction between voracity effect and growth of real GDP is positive, implying that a rise of in POLICONIII index leading to the increase of procyclicality. These findings are consistent with theories that explain procyclical biases on fiscal policy due to the voracity effect. Concerning other dimensions of democracy we find that, we show that the degree of constraints on the executive and political competition affect negatively procyclicality of government expenditure in MENA region. A political regime characterized by the absence of constraint on the decision-making powers of chief executive and the presence of government restriction on political competition lead countries to run sub optimal fiscal policies.

Institutional variables were considered as possible determinants of the cyclicality of fiscal policy and of the differences found between countries. As we can see in table 4, in general these variables play significant role. Quality of institution presents a statistical significance and its coefficient presents a negative sign suggestion that weak quality of institution tend to allow government expenditure to play its Keynesian stabilization role. This finding is unreal because countries may be able to run countercyclical policies if they have stronger institution. Concerning control of corruption and the effect of oil and Gas rent, their correlation's coefficients present expected sign. We conclude that procyclicality of government expenditure decrease with more control of corruption and low ratio of oil and gas rent. We argue that the abundance of natural resources will introduce distortions to the structure of the economy and in the quality of governance institutions of the country.

\section{Conclusion and Policy Implications}

There are strong evidences that fiscal policy is procyclical in MENA region: Fiscal expansions tend to take place in good times, and not during bad times when they might play some role in smoothing output declines. This applies to a variety of measures of fiscal policy - including the share of total expenditure in GDP, and the share of total revenue in GDP.

Fiscal procyclicality in MENA region arises from both the weakness of automatic stabilizers and the procyclical bias of discretionary policies. Despite the fact that in industrial countries countercyclical discretionary policy contributes to dampen aggregate fluctuations, in developing economies discretionary policy is usually procyclical. In addition, in most MENA countries automatic fiscal stabilizers - such as income taxes and transfer programs built into the fiscal system - are too small to have a significant smoothing effect on aggregate fluctuations.

Fiscal procyclicality as the consequence of fiscal stance in MENA region. Regarding the stance of fiscal policy in MENA region, we observe that high deficits characterise the economic history of these countries. The consequences of this situation have been destructive. By stimulating aggregate demand, high deficits can add to inflationary pressure and/ or put strain on balance of payment. It can also, accumulate large public debts, which eventually put pressure on interest and prices. They also, limit the ability of government to accommodate unexpected fiscal shocks and run a countercyclical fiscal policy.

Given that, we can explain the procyclicality of fiscal policy in MENA region as the result of high fiscal deficits and the accumulation of large public debts.

The procyclical bias in fiscal policy reflects underlying fundamental challenges facing developing countries. Our paper suggests that two main sets of factors account for this procyclicality of discretionary fiscal policy: (i) the inability of developing countries to access domestic and external finance to run countercyclical fiscal policy and (ii) political economy problems that contribute to an overspending of public revenues when they are abundant in good times. Such fundamental factors are difficult to overcome in the short run, suggesting deep underlying limits on the ability of most countries to run optimal fiscal policies in MENA region.

We argue that MENA countries are more likely to conduct optimal fiscal policy if they have: (i) a wider access to international capital Market, (ii) a deeper domestic financial markets, (iii) stronger institutional framework, and (iv) more less power dispersion. These results seem to be coherent with the notion that political distortions and structural market failures may explain the procyclical bias of fiscal policy in many developing countries.

Fiscal policies need to be credibly and sustainably financed. As noted above, lack of access to finance has been an important obstacle to expansionary fiscal policy during downturns in developing countries. Many MENA countries have limited capacity for domestic and external borrowing to finance increased spending, and monetizing fiscal deficits is potentially very risky. Regarding this, only those developing countries with strong fiscal positions and large reserve stocks can afford to finance a fiscal expansion during downturns. 
The fiscal expansion must be well- timed. There is consensus that fiscal interventions need to be timely in order to be effective, and that mistimed interventions can be counter-productive. This has been a challenge in MENA countries, where data quality (to identify downturns and recoveries in real time) and fiscal institutions (to design and implement any proposed spending increases) are weak.

Overall, MENA countries should consider two priorities in the use of fiscal policies as a hedge against macroeconomic fluctuations. Firstly MENA countries must develop again their domestic financial market and grant a wider access to international capital markets. Because the relaxing of credit constraints may give MENA countries fiscal space to run countercyclical policies. Secondly, institutional pre-requirement implies that MENA countries need to improve their institutional framework through more security of property right and controlling corruption.

Running optimal fiscal policies in MENA region requires a reduction of public indebtedness. This can only be achieved via reform of public finances, continued fiscal discipline and sustained economic growth. Enhancing and maintaining fiscal discipline will be facilitated by improving the institutional framework in which fiscal policy operates, via more effective budgetary management and transparency, and eventually via fiscal rules, which so far not being widely used in the region.

\section{References}

Agénor, P. R. \& Montiel, P. (1996). Development Macroeconomics. New Jersy: Princeton University Press.

Aguiar, M. \& Amador, M, \& Gopinath, G. (2005) .Efficient Fiscal Policy and Amplification. NBER Working Papers 11490

Alesina, A. \& Tabellini, G. (2005). Why is Fiscal Policy Often Procyclical? NBER Working Paper $n^{\circ} 11600$.

Akiboty, B, Clement, B, Gupta, S, \& Inchauste, G. (2004). The Cyclical and Long-Term Behavior of Government Expenditures in Developing Countries. International Monetary Fund, Working Paper $n^{\circ}$ 04/02.

Caballero, R, \& Krishnamurthy, A. (2004). Fiscal Policy and Financial Depth. NBER Working Paper $n^{\circ} 10532$.

Caldéron, C, \& Schmidt-Hebbel, K. (2008). Business Cycle and Fiscal Policies: The Role of Institutions and Financial Markets, Central Bank of Chili, Working Paper $n^{\circ} 481$.

Gavin, M, Hausmann, R, Perotti, R, \& Talvi, R. (1996). Managing Fiscal Policy in Latin America and the Caribbean: Volatility, Procyclicality, and Limited Creditworthiness. Inter-American Development Bank, Working Paper $n^{\circ} 326$.

Gavin, M, \& Perotti, R. (1997). Fiscal Policy in Latin America. NBER Macroeconomics Annual, 11-61.

Henisz, W. (2010). Measures of Political www-management.wharton.upenn.edu/henisz/_vti_bin/shtml.dl1/POLCON/ContactInfo.html

Hercowitz, Z, \& Strawczynski, M. (2004). Cyclical Ratcheting in Government Spending: Evidence from the OECD. Review of Economics and Statistics, 86, 353-361.

Ilzetzki, E, \& Végh, C. (2008). "Procyclical Fiscal Policy in Developing Countries: Truth or Fiction", NBER Working Paper $n^{\circ} 14191$.

Kaminsky, G, Reinhart, C, \& Végh, C. (2004). When it Rains, it's Pours: Procyclical Capital Flows and Macroeconomic Policies. NBER Macroeconomic Annual.

Lane, P.R. 2003. Business Cycle and Macroeconomic Policy in Emerging Market Economies. International Finance, 6, 89- 108 .

Lane, P.R. (2003). The Cyclical Behavior of Fiscal policy: Evidence from the OECD, Journal of Public Economics, 87, 2661-2675.

Riascos, A, \& Végh, C. (2003). Procyclical Government Spending in Developing Countries: the Role of Capital Market Imperfections. Mimeo. UCLA and Banco Republica, Colombia.

Tanzi, V, \& Davoodi, H. (1997). Corruption, Public Investment and Growth. International Monetary Fund Working Papers $n^{\circ}$ 97/139.

Talvi, E, \& Végh, C. (2005). Tax Base Variability and Procyclical Fiscal Policy in Developing Countries. Journal of Development Economics, 78, 156-90.

Torenell, A, \& Lane, P. (1999). The Voracity Effect. American Economic Review, 89, 22-46. 
Table 1. Cyclical proprieties of government expenditure

\begin{tabular}{|c|c|c|c|c|c|}
\hline \multirow[t]{3}{*}{ Models } & \multirow{3}{*}{$\frac{(1)}{\text { Diff-GMM }}$} & \multicolumn{3}{|c|}{ (2) } & \multirow{3}{*}{$\frac{\text { (3) }}{\text { Sys-GMM }}$} \\
\hline & & \multicolumn{3}{|c|}{ Diff-GMM } & \\
\hline & & Oil countries & MENA region & Non oil countries & \\
\hline GDP Growth & $\begin{array}{c}1.110525^{* * * *} \\
(3.16) \\
\end{array}$ & $\begin{array}{c}0.796810^{* * * *} \\
(5.01) \\
\end{array}$ & $\begin{array}{c}1.392835^{* * * *} \\
(3.36) \\
\end{array}$ & $\begin{array}{c}0.782985^{* * * *} \\
(3.46) \\
\end{array}$ & $\begin{array}{c}1.125416 \\
(3.12) \\
\end{array}$ \\
\hline Terms of trade growth & $\begin{array}{c}-0.683937^{*} \\
(-1.82) \\
\end{array}$ & $\begin{array}{c}-0.010937^{*} \\
(-1.70) \\
\end{array}$ & $\begin{array}{c}-0.277325^{*} \\
(-1.87) \\
\end{array}$ & $\begin{array}{c}-0.009022^{*} \\
(-1.70)\end{array}$ & $\begin{array}{c}-0.678189^{*} \\
(-1.79) \\
\end{array}$ \\
\hline Lagged growth of government spending & $\begin{array}{c}-.098795^{* *} \\
(-2.05) \\
\end{array}$ & $\begin{array}{c}-0.149399^{* *} \\
(-2.18) \\
\end{array}$ & $\begin{array}{c}-0.057927 \\
(-1.80)^{*}\end{array}$ & $\begin{array}{c}-0.210975^{* * *} \\
(-3.18) \\
\end{array}$ & $\begin{array}{r}-0.08314^{* *} \\
(-1.99) \\
\end{array}$ \\
\hline Inflations & & $\begin{array}{c}0.000106 \\
(0.03)\end{array}$ & $\begin{array}{c}0.035906 \\
(0.77)\end{array}$ & $\begin{array}{c}0.000517 \\
(0.43)\end{array}$ & \\
\hline Trade openness & & $\begin{array}{c}0.003961 \\
(1.36)\end{array}$ & $\begin{array}{c}0.025199 \\
(1.28) \\
\end{array}$ & $\begin{array}{c}0.001245 \\
(1.21)\end{array}$ & \\
\hline Dependency ratio & & $\begin{array}{c}0.003082 \\
(0.93)\end{array}$ & $\begin{array}{c}-0.823179 \\
(-0.69) \\
\end{array}$ & $\begin{array}{c}0.001474^{*} \\
(1.70)\end{array}$ & \\
\hline Urban population ratio & & $\begin{array}{c}-0.001201 \\
(-0.31) \\
\end{array}$ & $\begin{array}{c}-0.095102 \\
(-0.55) \\
\end{array}$ & $\begin{array}{c}-0.003507 \\
(-1.26) \\
\end{array}$ & \\
\hline Observations & 215 & 125 & 215 & 90 & 215 \\
\hline Arrelano-Bond test for AR(1) & 0.003 & 0.001 & 0.006 & 0.001 & 0.003 \\
\hline Arrelano-Bond test for AR(2) & 0.714 & 0.354 & 0.310 & 0.360 & 0.723 \\
\hline Hansen test & 0.274 & 0.586 & 0.410 & 0.515 & 0.283 \\
\hline Sargan test & 0.066 & 0.085 & 0.079 & 0.056 & 0.088 \\
\hline
\end{tabular}

Significant at $10 \%$ level, ** significant at $5 \%$ level, *** significant at $1 \%$ level. Values of T statistics in parentheses. We report the p-values for the Hansen test of over-identifying restrictions and the Arellano-Bond test for AR (1) and AR (2) in first difference.

Table 2. Financing constraints, impact on procyclicality

\begin{tabular}{|c|c|c|}
\hline Models & (4) & (5) \\
\hline & Diff-GMM & Diff-GMM \\
\hline GDP growth & $\begin{array}{c}0.840584^{* *} \\
(2.33) \\
\end{array}$ & $\begin{array}{c}0.789205^{* *} \\
(2.50)\end{array}$ \\
\hline Terms of trade growth & $\begin{array}{c}-0.001728^{*} \\
(-1.79)\end{array}$ & $\begin{array}{c}-0.001909^{*} \\
(-1.72)\end{array}$ \\
\hline Lagged in government spending & $\begin{array}{c}-0.043312^{*} \\
(-1.77)\end{array}$ & $\begin{array}{c}-0.177774^{*} * \\
(-2.30)\end{array}$ \\
\hline Financial openness & $\begin{array}{c}0.135018^{* * * *} \\
(2.97) \\
\end{array}$ & \\
\hline Financial depth & & $\begin{array}{c}0.013325^{* *} \\
(1.99)\end{array}$ \\
\hline Observations & 215 & 215 \\
\hline Arrelano-Bond test for AR(1) & 0.001 & 0.003 \\
\hline Arrelano-Bond test for AR(2) & 0.587 & 0.398 \\
\hline Hansen test & 0.216 & 0.366 \\
\hline Sargan test & 0.074 & 0.055 \\
\hline
\end{tabular}

* Significant at $10 \%$ level, ${ }^{* *}$ significant at $5 \%$ level, ${ }^{* * *}$ significant at $1 \%$ level. Values of $\mathrm{T}$ statistics in parentheses. 
Table 3. Political factors, impact on procyclicality

\begin{tabular}{|c|c|c|c|c|}
\hline & (6) & (7) & (8) & (9) \\
\hline & Diff-GMM & Diff-GMM & Diff-GMM & Diff-GMM \\
\hline Real output & $\begin{array}{c}0.755667^{* * * *} \\
(3.60) \\
\end{array}$ & $\begin{array}{c}0.722122^{* *} \\
(2.22) \\
\end{array}$ & $\begin{array}{c}0.795767^{* * *} \\
(3.04) \\
\end{array}$ & $\begin{array}{c}0.822517^{* * * *} \\
(3.05) \\
\end{array}$ \\
\hline Terms of trade growth & $\begin{array}{c}-0.003025^{*} \\
(-1.74)\end{array}$ & $\begin{array}{c}-0.002731^{*} \\
(-1.95)\end{array}$ & $\begin{array}{c}-0.001977^{*} \\
(-1.85)\end{array}$ & $\begin{array}{c}-0.002963^{*} \\
(-1.89)\end{array}$ \\
\hline Lagged in government spending & $\begin{array}{c}-0.210749^{* *} \\
(-2.05) \\
\end{array}$ & $\begin{array}{c}-0.258907^{* *} \\
(-1.98) \\
\end{array}$ & $\begin{array}{c}-0.375422^{* *} \\
(-2.22)\end{array}$ & $\begin{array}{c}-0.200551^{* *} \\
(-2.06)\end{array}$ \\
\hline Democracy & $\begin{array}{c}0.014494^{*} \\
(1.80)\end{array}$ & & & \\
\hline Degree of constraints on the executive & & $\begin{array}{c}-0.134532^{*} \\
(-1.86) \\
\end{array}$ & & \\
\hline Political competition & & & $\begin{array}{c}-0.011409^{*} \\
(-1.79) \\
\end{array}$ & \\
\hline polconIII & & & & $\begin{array}{c}-0.018075^{*} \\
(-1.73)\end{array}$ \\
\hline Observations & 215 & 215 & 215 & 215 \\
\hline Arrelano-Bond test for AR(1) & 0.001 & 0.005 & 0.003 & 0.001 \\
\hline Arrelano-Bond test for AR(2) & 0.276 & 0.785 & 0.652 & 0.423 \\
\hline Hansen test & 0.266 & 0.322 & 0.289 & 0.634 \\
\hline Sargan test & 0.077 & 0.063 & 0.088 & 0.059 \\
\hline
\end{tabular}

* Significant at $10 \%$ level, ** significant at $5 \%$ level, ${ }^{* * *}$ significant at $1 \%$ level. Values of $\mathrm{T}$ statistics in parentheses.

Table 4. institutional factors, impact on procyclicality

\begin{tabular}{|c|c|c|c|}
\hline Models & (10) & (11) & (12) \\
\hline & Diff-GMM & Diff-GMM & \\
\hline Real output & $\begin{array}{c}0.829471^{* *} \\
(2.18) \\
\end{array}$ & $\begin{array}{c}0.770217^{* *} \\
(2.07) \\
\end{array}$ & $\begin{array}{c}0.795016^{* * *} \\
(3.07) \\
\end{array}$ \\
\hline Terms of trade growth & $\begin{array}{c}-0.003105^{*} \\
(-1.81)\end{array}$ & $\begin{array}{c}-0.007724^{*} \\
(-1.95)\end{array}$ & $\begin{array}{c}-0.002124^{*} \\
(-1.84)\end{array}$ \\
\hline Lagged in government spending & $\begin{array}{c}-0.030199^{* *} \\
(1.98)\end{array}$ & $\begin{array}{c}-0.012726^{* *} \\
(-2.09)\end{array}$ & $\begin{array}{c}-0.483162^{*} \\
(-1.73)\end{array}$ \\
\hline Quality of institution & $\begin{array}{c}-0.002428^{* * *} \\
(-5.14)\end{array}$ & & \\
\hline Corruption & & $\begin{array}{c}0.041352^{* *} \\
(2.12)\end{array}$ & \\
\hline Oil and Gas rent & & & $\begin{array}{c}0.001357^{*} \\
(1.88)\end{array}$ \\
\hline Observations & 215 & 215 & 215 \\
\hline Arrelano-Bond test for AR(1) & 0.003 & 0.002 & 0.001 \\
\hline Arrelano-Bond test for $\mathrm{AR}(2)$ & 0.386 & 0.541 & 0.379 \\
\hline Hansen test & 0.287 & 0.369 & 0.744 \\
\hline Sargan test & 0.054 & 0.068 & 0.077 \\
\hline
\end{tabular}

* Significant at $10 \%$ level, ** significant at $5 \%$ level, $* * *$ significant at $1 \%$ level. Values of $\mathrm{T}$ statistics in parentheses. 